\title{
Mammary Gland Involution Provides a Unique Model to Study the TGF- $\beta$ Cancer Paradox
}

\author{
Qiuchen Guo ${ }^{1,+}$, Courtney Betts ${ }^{1,+}$, Nathan Pennock ${ }^{1,+}$, Elizabeth Mitchell ${ }^{1}$ and \\ Pepper Schedin $1,2,3, *$ \\ 1 Department of Cell, Developmental and Cancer Biology, Oregon Health and Science University, Portland, \\ OR 97239, USA; guo@ohsu.edu (Q.G.); bettsc@ohsu.edu (C.B.); pennock@ohsu.edu (N.P.); \\ mitceliz@ohsu.edu (E.M.) \\ 2 Young Women's Breast Cancer Translational Program, University of Colorado Anschutz Medical Campus, \\ Aurora, CO 80045, USA \\ 3 Knight Cancer Institute, Oregon Health and Science University, Portland, OR 97239, USA \\ * Correspondence: Schedin@ohsu.edu; Tel.: +1-503-494-9341 \\ + These authors contributed equally to this work.
}

Academic Editor: Andrei Turtoi

Received: 13 November 2016; Accepted: 27 December 2016; Published: 13 January 2017

\begin{abstract}
Transforming Growth Factor- $\beta$ (TGF- $\beta$ ) signaling in cancer has been termed the "TGF- $\beta$ paradox", acting as both a tumor suppresser and promoter. The complexity of TGF- $\beta$ signaling within the tumor is context dependent, and greatly impacted by cellular crosstalk between TGF- $\beta$ responsive cells in the microenvironment including adjacent epithelial, endothelial, mesenchymal, and hematopoietic cells. Here we utilize normal, weaning-induced mammary gland involution as a tissue microenvironment model to study the complexity of TGF- $\beta$ function. This article reviews facets of mammary gland involution that are TGF- $\beta$ regulated, namely mammary epithelial cell death, immune activation, and extracellular matrix remodeling. We outline how distinct cellular responses and crosstalk between cell types during physiologically normal mammary gland involution contribute to simultaneous tumor suppressive and promotional microenvironments. We also highlight alternatives to direct TGF- $\beta$ blocking anti-cancer therapies with an emphasis on eliciting concerted microenvironmental-mediated tumor suppression.
\end{abstract}

Keywords: weaning-induced mammary gland involution; TGF- $\beta$; cellular crosstalk; cancer

\section{Introduction}

The function of transforming growth factor $\beta$ (TGF- $\beta$ ) signaling in cancer remains a paradox, as TGF- $\beta$ has both tumor suppressive and promotional activities [1,2]. The conflicting data as to whether TGF- $\beta$ acts dominantly as a tumor suppressor or promotor are largely context dependent, that is, contingent on the transformed state of the tumor cell and the constituents of the tumor microenvironment [2]. Tumor cell intrinsic properties that impact TGF- $\beta$ signaling include genetic alterations in the pathway, however, the local tumor microenvironment plays a central role in determining if a tumor cell is ultimately suppressed or activated by TGF- $\beta$. This is because most cell types respond to TGF- $\beta$ stimulation [3-5], and coordinated crosstalk between various cell types is required to integrate TGF- $\beta$ signaling across the tissue. Furthermore, based on the types of TGF- $\beta$ responding cells within the tissue, pro- and anti-tumor signals can be generated simultaneously.

In this review, we explore the dual nature of TGF- $\beta$ function in cancer by investigating several of the myriad roles of TGF- $\beta$ within the context of normal tissue biology, using weaning-induced mammary gland involution as a model. Weaning-induced mammary gland involution is TGF- $\beta$-dependent, with direct roles described for epithelial cell apoptosis and cell clearance [6,7], 
immune modulation [4], and extracellular matrix remodeling [8]. We argue that exploring tissue level TGF- $\beta$ biology using this multicellular integrated approach is critical for understanding how to successfully target TGF- $\beta$ for cancer therapeutics.

\section{The TGF- $\beta$ Cancer Paradox}

The TGF- $\beta$ paradox has been well described in the context of epithelial cells $[3,9]$. TGF- $\beta$ is well known to operate through two key pathways, termed the canonical and non-canonical signaling pathways, which have been studied and reviewed intensively elsewhere [10-12]. While the molecular activities downstream of these pathways are distinct, their differential employment does not explain the tumor observed TGF- $\beta$ paradox. In normal epithelium, key tumor suppressive capacities of TGF- $\beta$ include inhibiting normal epithelial cell proliferation and inducing apoptosis [3], functions thought to be required for blocking progression of initiated cancer cells [13]. Early studies showed that TGF- $\beta$ treatment of primary, non-transformed rabbit uterine epithelial cells inhibited cell proliferation and induced apoptosis in a concentration dependent manner [14]. Subsequently, researchers discovered that TGF- $\beta$ inhibits cell proliferation by blocking the late G1 activation of the cyclin-dependent kinases [15] and induces cell apoptosis by upregulating the Death-Associated Protein kinase, a caspase mediated extrinsic apoptotic kinase, which can also be triggered by FAS (tumor necrosis factor receptor superfamily, member 6) and tumor necrosis factor $\alpha(\mathrm{TNF} \alpha)$ receptor ligation [16-18]. Cell culture studies have shown that TGF- $\beta$ treatment induced apoptosis in a variety of primary epithelial cells and established immortalized but non-transformed cells, including hepatocytes [19], colonic epithelial cells [20], and mammary epithelial cells [21]. TGF- $\beta$ also can inhibit carcinogenesis. For example, a mixed strain of Rag2 ${ }^{-/-}$mice (129S6 $\times$CF-1) develops an inflammation associated hyperplasia specific to cecum and colon [22]. In this mouse model, the combination of inflammation associated hyperplasia with loss of TGF- $\beta$ is sufficient to promote the development of overt colon cancers [22]. Cumulatively, these data support a key role for TGF- $\beta$ in tumor suppression.

In contrast to the described tumor suppressive functions of TGF- $\beta$, this cytokine has also been shown to support tumor progression through various tumor cell intrinsic mechanisms. With tumor progression, tumor cells can acquire resistance to TGF- $\beta$ growth inhibition by downregulation or mutation of the TGF- $\beta$ receptors (TGF- $\beta$ R) [23] or TGF- $\beta$ pathway downstream effectors such as Smad4 [24], a coactivator in the canonical TGF- $\beta$ pathway [25]. In many epithelial cancer cell lines, the inhibitory effects of TGF- $\beta$ signaling are not simply bypassed, but rather TGF- $\beta$ signaling becomes cancer promotional. This occurs via TGF- $\beta$ induction of epithelial-mesenchymal transition (EMT), as measured by downregulation of the epithelial cell markers E-cadherin, and upregulation of the mesenchymal marker vimentin [26]. Furthermore, TGF- $\beta$ can enhance stemness properties of tumor cells including colony formation, in vivo tumor growth, and chemotherapy drug resistance $[27,28]$. Additional early evidence that TGF- $\beta$ facilitates cancer progression was observed in a rat model, where a mammary adenocarcinoma clone of the MTLn3 cell line was injected through the tail vein of syngeneic F344/NHSd female rats. TGF- $\beta$ pre-treatment of the tumor cells prior to tail vein injection resulted in a three-fold increase in lung metastases [29]. In total, experimental data support the hypothesis that more advanced cancers are promoted by TGF- $\beta$ signaling, and led to the development of TGF- $\beta$ inhibitors for cancer therapy.

Currently, more than 30 anti-TGF- $\beta$ drugs have been developed and evaluated in preclinical and clinical trials, results of which are excellently reviewed elsewhere [30-33]. In sum, anti-TGF- $\beta$ drugs have had limited and sporadic efficacy in clinical cancer treatment [30-33]. In a phase III clinical study with 270 patients with non-small cell lung cancer, treatment with the TGF- $\beta$ antisense oligonucleotides drug Belagenpumatucel-L did not impact patients' progression-free survival or overall survival [33]. Similarly, T $\beta$ M1, a monoclonal antibody against TGF- $\beta 1$, showed no effect in patients with metastatic colon and rectal cancers [34]. Importantly, understanding the impact of TGF- $\beta$ signaling in the context of tumor cell intrinsic biology has not provided a clear explanation for the lack of robust clinical efficacy in these clinical trials. A relatively unexplored explanation for these results is based upon the fact 
that most cell types in the body respond to TGF- $\beta$ stimulation. Thus, the resulting cellular crosstalk dramatically complicates the biology and outcome of TGF- $\beta$ inhibition in cancer patients. To begin to understand this tissue-level complexity and how it can impact clinical efficacy, we discuss TGF- $\beta$ signaling in the context of weaning-induced mammary gland involution, where TGF- $\beta$ impacts distinct cell types and their crosstalk to coordinate key biological processes. Many of these biological processes are shared with those characterized in both promotional and suppressive tumor microenvironments, making involution a unique model to shed light on the TGF- $\beta$ cancer paradox.

\section{Mammary Gland Involution as a Model to Integrate Disparate TGF- $\beta$ Biology}

The mammary gland is dynamically regulated by reproductive state. During pregnancy, as the gland prepares for milk production and secretion, the mammary gland expands dramatically through extensive epithelial cell proliferation and differentiation [35]. After lactation, the mammary gland undergoes weaning-induced mammary gland involution, whereby unnecessary secretory epithelial cells are eliminated through a concerted, developmentally regulated cell death and tissue remodeling program [36-40]. Using rodent models, lactational load is normalized and involution synchronized by standardizing pup removal, allowing for the cellular and molecular events of involution to be analyzed in detail (Figure 1). The hallmark features of involution include clearance of $\geq 80 \%$ of the mature, secretory mammary epithelium through programmed cell death [37,41], adipocyte repopulation [42], and immune cell infiltration and extracellular matrix (ECM) deposition consistent with wound healing [43-45]. This developmentally regulated window of tissue regression captures the spectrum of TGF- $\beta$ functions including processes that are conventionally tumor suppressive (epithelial cell apoptosis) as well as tumor promotional (ECM deposition and immune suppression). The cell death that occurs during involution is consistent with tumor suppression, as clearance of early transformed epithelial cells can likely prevent tumor formation [46]. However, the intensive stromal remodeling and immune suppression that occurs with involution is known to promote pre-existing tumor cells $[45,47,48]$. In fact, the co-existence of both tumor suppressive and promotional attributes within the involuting mammary gland may help explain the dual effect pregnancy has on breast cancer incidence as well as prognosis [46,49], a topic that is addressed more fully below.

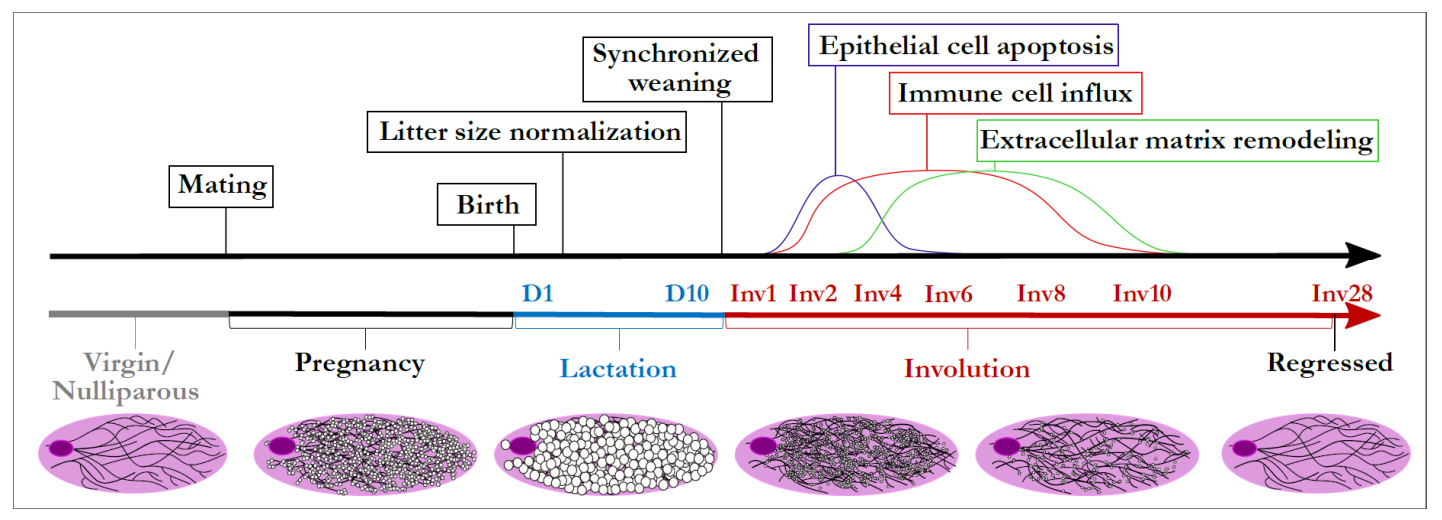

Figure 1. Rodent model of synchronized weaning-induced mammary gland involution. Male and female rodents are mated for 3-5 days. After pup birth, litter size is normalized to ensure equal lactation load per dam, and weaning initiated during peak lactation (9-13 days) by pup removal. The kinetics of three major cellular events during involution are shown in the above timeline: epithelial cell apoptosis, immune cell influx, and extracellular matrix remodeling. Days since start of lactation are indicated by " $\mathrm{D}$ " followed by a number, and days since synchronized weaning by "Inv". Whole gland representations of mammary epithelial ducts (black lines) as well as milk accumulation (white filled circles) are displayed below the corresponding developmental stages in the timeline. 


\section{Evidence for TGF- $\beta$ Orchestrating Weaning-Induced Mammary Gland Involution}

One of the first events of mammary gland involution is the initiation of epithelial cell apoptosis. (Figure 2A, upper panel). With weaning, the majority of epithelial cells undergo cathepsin and caspase mediated cell death [50,51], as a means to remove the mature milk secreting cells. Multiple signaling pathways are involved in initiating epithelial cell death during involution, including Janus kinase 1 (JAK1), leukemia inhibitory factor (LIF), dedicator of cytokinesis 1 (Dock1), nuclear factor k-light chain enhancer of $B$ cells/tumor necrosis factor $(\mathrm{NFKB} / \mathrm{TNF})$, and most relevant for the purposes of this review, TGF- $\beta$. Impairment in any of these pathways can result in delayed involution [6,52-55]. Over the past 20 years of investigation, many insightful experiments have been performed to elucidate the timing and significance of TGF- $\beta$ activation in facilitating mammary gland involution. TGF- $\beta$ cytokine signaling can be initiated by expression of any of three functionally identical TGF- $\beta$ genes, which differ in cellular and developmental levels of expression. By mRNA and protein analyses, TGF- $\beta 3$ is the most abundant subtype of TGF- $\beta$ in the mouse mammary gland and levels also increase sharply with weaning $[6,7,39]$. Epithelial sources of TGF- $\beta 3$ were determined to be sufficient to support epithelial cell apoptosis, through experimental implementation of a conditional transgenic mouse in which $T g f b 3$ overexpression in mammary epithelium was driven by the $\beta$-lactoglobulin promoter [6]. In this model, at day 1 of involution, overexpression of $T g f b 3$ in the epithelial compartment increased epithelial cell apoptosis. Importantly the epithelial cells themselves illustrated nuclear localization of Smad4, emphasizing the potential importance of autocrine canonical TGF- $\beta$ signaling in epithelial cell death [6]. Mechanistically, recent studies have shown the miR-424/503 cluster, which can be upregulated downstream of canonical TGF- $\beta$-Smad activation, participates in mammary epithelial cell death during involution by means of B-cell lymphoma 2 (BCL-2) and insulin-like growth factor 1 (IGF1) receptor downregulation [56,57]. Collectively, these studies provide detailed evidence of the active participation of TGF- $\beta$ signaling during the initiation of involution.

To more directly assess the unique role of TGF- $\beta$ during involution, additional evidence is required, for example, by deleting either the gene for the TGF- $\beta$ cytokine or the TGF- $\beta$ R. Unfortunately, loss of TGF- $\beta$ function by gene knockout (KO) is difficult to address, as TGF- $\beta$ is needed for normal embryonic development and fetal survival, with $T g f b 3 \mathrm{KO}$ mice living for approximately two weeks after birth before succumbing to severe pulmonary abnormalities [58,59]. Furthermore, because of TGF- $\beta$ 's broad systemic influence, to glean the importance of TGF- $\beta$ in specific events, more sophisticated experiments must be devised that relegate TGF- $\beta$ signaling alterations to a specific tissue and/or during a particular window of interest. A novel mammary gland transplantation model was devised to circumvent this limitation, permitting the evaluation of TGF- $\beta$ function in the post-neonate mammary gland [6]. In this model, mammary glands of newborn pups carrying a null mutation in the $T g f b 3$ gene were harvested and placed into wild-type females whose mammary glands were removed before transplantation. Loss of the $T g f b 3$ gene within the mammary gland did not impact pubertal gland development or pregnancy, however, loss of $T g f b 3$ did result in a three-fold decrease in epithelial cell apoptosis at day 1 post-weaning [6]. Similar results were also obtained in an epithelial lineage specific and temporally controlled conditional KO mouse model in which floxed Tgfbr 2 was ablated by a Whey Acidic Protein (WAP) promoter driven-Cre transgene, resulting in temporal deletion of TGF- $\beta$ RII within mammary epithelial cells starting at lactation. In this model, mammary epithelial cell specific $T g f b r 2$ loss resulted in prolonged lactation and delayed epithelial cell death upon weaning, data consistent with roles for TGF- $\beta$ signaling in the initiation of involution as well as epithelial cell death [60]. In summary, TGF- $\beta$ has been discovered to be a necessary player in mammary gland involution and justifies involution as a strong model for understanding many TGF- $\beta$ signaling processes. 


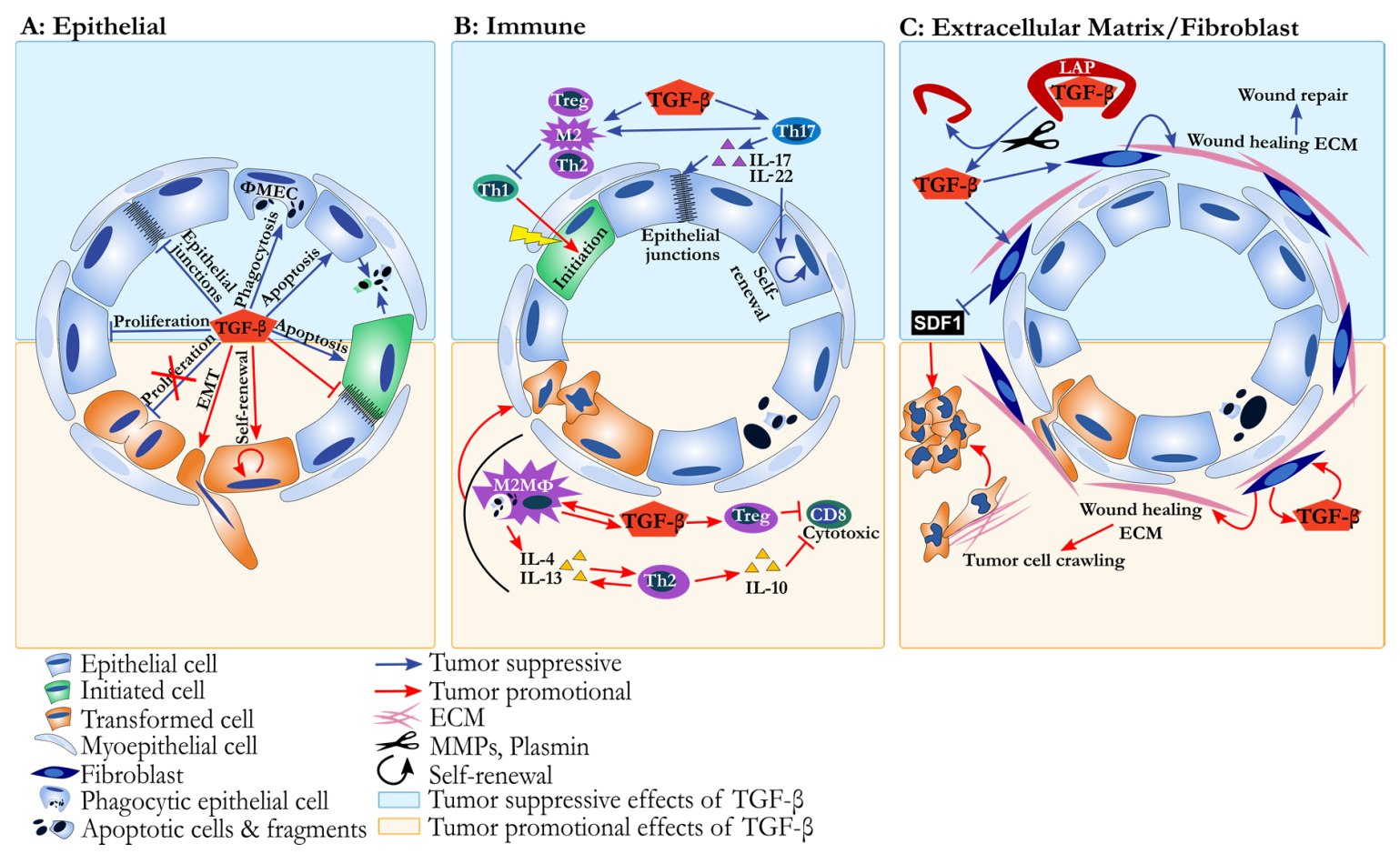

Figure 2. The tumor suppressive and promotional functions of transforming growth factor $\beta$ (TGF- $\beta$ ) in the involuting mammary microenvironment. Each panel depicts an involuting mammary acini either lacking (top panel) or containing (bottom panel) tumor cells. (A) Epithelium: In non-transformed mammary epithelial cells (top half of diagram, blue arrows), TGF- $\beta$ suppresses cell proliferation, and induces tumor suppressive apoptosis and phagocytosis mediated by loss of epithelial junctions. In the presence of transformed cells (bottom half of diagram, red arrows), TGF- $\beta$ can promote cancer progression by inducing epithelial mesenchymal transition (EMT) and stem cell phenotypes. Additionally, anti-proliferative functions of TGF- $\beta$ can be lost in tumor cells via mutations in TGF- $\beta$ signaling pathways (depicted by red X); (B) Immune milieu: In the absence of tumor cells (top half of diagram, blue arrows), TGF- $\beta$ suppresses chronic inflammation by inducing T-helper 2 (Th2) cells and T-helper 17 (Th17) cells which can suppress T-helper 1 (Th1) cells mediated tumor initiation. This immune environment also maintains epithelial stem cell health and epithelial cell junctional integrity (blue arrows). In the presence of tumor cells (bottom half of diagram, red arrows), TGF- $\beta$ induced Th2 immunity suppresses anti-cancer CD8 T cell cytotoxic function and directly activates tumor cells through growth factor/cytokine signaling; (C) Extracellular matrix/fibroblast: Active TGF- $\beta$ is released in the extracellular microenvironment when proteases cleave the Latency Associated Peptide (LAP). TGF- $\beta$ signaling within fibroblasts impairs production of stromal cell-derived factor-1 (SDF1). In the absence of tumor, TGF- $\beta$ signaling plays a critical role in maintaining tissue integrity (top half of diagram, blue arrows). In the presence of tumor cells (bottom half of diagram, red arrows) a wound healing like extracellular matrix environment provides stratum and accompanying signals for cancer cell motility and invasive phenotypes.

TGF- $\beta$ is not only involved in the induction of epithelial cell apoptosis during involution, but also facilitates the clearance of the dying epithelial cells (Figure 2A, upper panel). During weaning, apoptotic epithelial cells are removed primarily within the first $72 \mathrm{~h}$ of involution, and somewhat surprisingly, clearance is largely accomplished by epithelial cells that do not succumb to early cell death, but rather become phagocytic [61]. Recently, TGF- $\beta 3$ has been shown to be sufficient to induce a phagocytic phenotype in mature mammary epithelial cells cultured under conditions that mimic epithelial tight junction closure unique to the lactating gland [7]. In this model, TGF- $\beta 3$ treatment led to $\gamma$-secretase induced cleavage of E-cadherin followed by $\beta$-catenin nuclear localization. This process resulted in downregulation of cell junction genes including cadherins and induction of a 
phagocytic phenotype in the epithelial cells [7]. TGF- $\beta 3$ induced mammary epithelial cell phagocytosis was characterized by loss of adherens junctions but was independent of EMT, although EMT is a common transformed epithelium response to TGF- $\beta$ (Figure 2A). Rather, in these normal, phagocytic mammary epithelial cells, the EMT associated genes, such as Snail1, Snail2, Twist1, Twist2, Zeb1, Vimentin, and Fibronectin 1 were not increased with TGF- $\beta 3$ treatment [7]. The function of TGF- $\beta$ in inducing epithelial cell phagocytosis is not restricted to the mammary gland and was first reported in human retinal pigment epithelial cells [62], illustrating a rarely appreciated but potentially more broadly conserved role of TGF- $\beta$ in epithelial cells. The consequences of TGF- $\beta$ induced epithelial cell apoptosis and phagocytosis during mammary gland involution provides one potential mechanism by which the involution window may be tumor suppressive, i.e., by eliminating potential targets of transformation (Figure 2A). However, cell death and phagocytosis have effects on the mammary tissue microenvironment not solely intrinsic to alterations in the epithelial cell compartment that must also be considered, including immune modulation.

The process of apoptosis actively suppresses the pro-inflammatory arm of the immune system [63]. Specifically, uptake of apoptotic cells by professional cell phagocytes, including macrophages, induces TGF- $\beta$ production that directly mediates immune suppression [64-66]. During involution, immune suppression appears to be an important part of the developmental process that allows for careful restructuring of the normal mammary gland to its baseline, non-secretory state [67]. If cancer cells are present during involution and do not undergo apoptosis, these tumor cells could gain an advantage due to impaired anti-tumor immunity. Thus, this intimate link between TGF- $\beta$ induced apoptosis in epithelial cells and immunosuppression provides one example of how TGF- $\beta$ can elicit, at the same time, tumor suppressive and promotional activities, a concept explored more fully below.

\section{TGF- $\beta$ in Developmental Immune Tolerance and the Inhibition of Cytolytic Immunity}

Throughout all tissues, TGF- $\beta$ has several discrete immune modulatory functions that overall serve to suppress destructive immune activation that could compromise host viability and/or disrupt finely orchestrated developmental processes. Within the lymphoid branch of immunity, TGF- $\beta$ is known to directly impair mature T cell proliferation. In immature and naïve T cells, TGF- $\beta$ also initiates upregulation of the transcription factor FOXP3, which drives differentiation of "regulatory" $\mathrm{T}$ cells (Tregs) [68]. Tregs actively impair the actions of cytotoxic (Th1) and cytolytic (Tc1) T cells and are therefore critical for maintaining immune tolerance and tissue homeostasis. Loss of Tregs alone is sufficient to result in devastating multi-organ autoimmunity [69]. In the myeloid branch of immunity, TGF- $\beta$ stimulates chemotaxis of immature monocytes [70] and plays an important role in the polarization and differentiation of immature myeloid cells to what is referred to as an "M2" macrophage phenotype [71-73]. As a result of the M2 program, macrophages produce the cytokines interleukin-4 (IL-4) and interleukin-13 (IL-13) [74]. These cytokines then further polarize the tissue microenvironment by driving differentiation of naïve $\mathrm{T}$ cells to a Th2 differentiated state. Molecularly, the Th2 state is achieved through activation of the transcription factor GATA3 [75] chiefly consequent of the signal transducer and activator of transcription 6 (STAT6) activation initiated by signaling via IL-4 and IL-13 receptors [76]. These TGF- $\beta$-induced M2, Treg, and Th 2 cell populations all secrete TGF- $\beta$ and interleukin-10 (IL-10), further enhancing suppression of damaging pro-inflammatory and immune cytolytic functions, and instead facilitate tissue rebuilding/remodeling processes.

In the post-weaning mammary gland, we and others have reported dramatic temporal changes in the abundance and types of the TGF- $\beta$ dependent immune cells discussed above $[37,39,45,77]$ (Figure 3). During involution we have observed an increase in number and proportion of regulatory $\mathrm{T}$ cells, immature myeloid cells, and M2 macrophages. Consistent with these observations we also noted increases in the immunosuppressive cytokines IL-4, IL-13, and IL-10 during involution [43,45] (Figure 2B). Rather surprisingly, macrophage/monocyte derived cells are not only present at an increased frequency but were also found necessary for the initiation of involution itself [67], yet again illustrating a finely orchestrated relationship between immunity and this developmentally regulated, 
tissue remodeling process. Cumulatively, these immune profiling data are consistent with expected roles in developmental tissue reconstruction and promoting immune tolerance.

The link between the coordinated death that occurs in the mammary gland with weaning and immune suppression likely exists to minimize self-antigen exposure to tissue resident and local lymphatic immune cells. It could be argued that establishment or maintenance of immune tolerance to these self-antigens would be of paramount importance for subsequent nursing as well as long-term host survival. While not yet formally demonstrated in the mammary gland, inference drawn from other locations throughout the body is consistent with a role for regulatory $\mathrm{T}$ cell subsets mediating this protection via TGF- $\beta$ signaling. Cumulatively, the observed increases in IL-10, immature myeloid cells, regulatory T cells, and M2 macrophages would predict that the immune environment during involution is staged to hinder immunity. While these TGF- $\beta$ associated immune processes would seem ideal in the involuting mammary gland, they may come at the cost of actively impairing anti-tumor immunity [77-79] (Figure 2B).

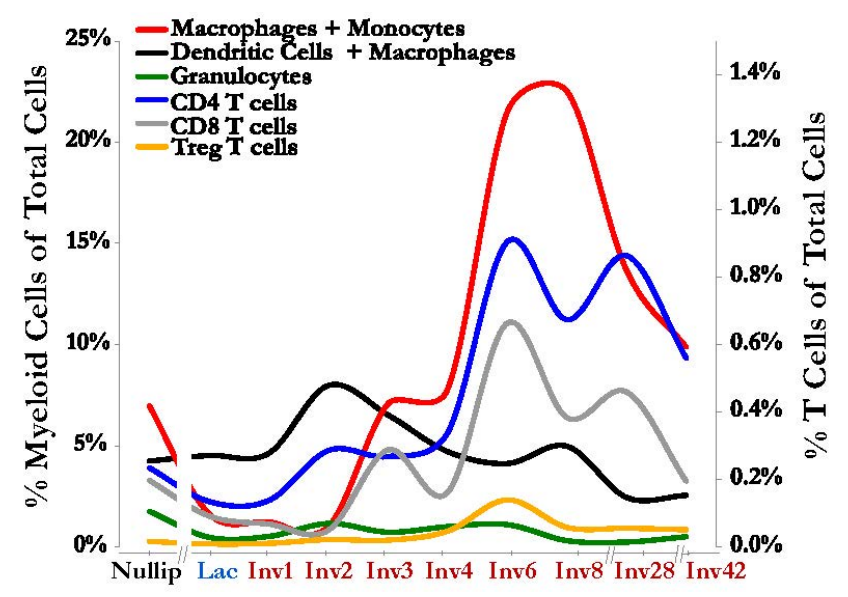

Figure 3. Immune cells increase in the mammary gland during involution. An influx of immune cells consistent with classic wound healing is observed during mammary gland involution including various myeloid cell populations (left axis): Macrophages and monocytes (CD45 ${ }^{+} \mathrm{Gr} 1^{\text {intermediate/low }}$ $\mathrm{F} 480^{+} \mathrm{CD} 11 \mathrm{~b}+$, red line); dendritic cells and macrophages (CD45+ CD11c+ MHCII+, black line); and granulocytes $\left(\mathrm{CD} 45^{+} \mathrm{Gr} 1^{\text {high }} \mathrm{F} 480^{-} \mathrm{CD} 11 \mathrm{~b}^{+}\right.$, green line). $\mathrm{T}$ cells are also increased in the mammary gland during involution (right axis): $\mathrm{CD} 4 \mathrm{~T}$ cells $\left(\mathrm{CD} 45^{+} \mathrm{CD} 3^{+} \mathrm{CD} 4^{+}\right.$, blue line), CD8 $\mathrm{T}$ cells (CD45 ${ }^{+}$ $\mathrm{CD}^{+} \mathrm{CD}^{+}$, gray line) and the immunosuppressive Treg T cells $\left(\mathrm{CD} 45^{+} \mathrm{CD}^{+} \mathrm{CD}^{+} \mathrm{FoxP}^{+} \mathrm{CD} 25^{+}\right.$, orange line). On the $X$-axis, the involution window is labeled in red, as "Inv" followed by a number for the day post-weaning. Both axes represent frequencies of indicated cell populations as a fraction of total cells from the gland, as determined by single cell suspensions analyzed by flow cytometry. The Figure is derived from data reported in Reference [45].

\section{The Immune Environment of Involution Is Tumor Promotional and Targetable}

Utilizing the mouse model of mammary gland involution, we have shown the involuting mammary microenvironment supports tumor progression significantly more than the mammary gland of the nulliparous host [48,80,81]. This feature is conserved in fully immune competent mice [45], demonstrating that an intact immune system does not mount a sufficient anti-tumor immune response during the involution window. Furthermore, we sought to determine whether the immune phenotypes characterized during involution where carried forward into the tumor microenvironment. We observed tumors injected into immune competent animals during the TGF- $\beta$ rich involution window are surrounded and infiltrated with increased numbers of immature myeloid cells, M2 macrophages, and T cells expressing IL-10 compared to their nulliparous counterparts; an immune signature associated with pro-tumor immunity. Moreover, IL-10 blockade through antibody administration reduced the observed growth advantage compared to genetically identical tumors implanted into nulliparous hosts, 
demonstrating the presence of a tumor promotional immune response in the involuting gland [45]. This effective pathway-targeted approach to thwarting specific TGF- $\beta$ driven immune effects was derived by considering the biology of the entire mammary gland microenvironment. This approach is important, as we have mentioned previously that global TGF- $\beta$ inhibition has proven to be challenging, likely due to confounding, tissue-level TGF- $\beta$ signals. With increasing knowledge from within immunity alone, these TGF- $\beta$ centric interventional outcomes might be predictable, as TGF- $\beta$ 's impact on immune cell function is also both pro- and anti-tumor, depending upon tissue context.

\section{TGF- $\beta$ and Th17 Promote Barrier Function, Reducing Inflammation and Tumor Initiation}

Considering only the TGF- $\beta$ meditated M2/Th2 biology described above, blockade of TGF- $\beta$ signaling would be predicted to enhance anti-tumor immunity. However, in mice where TGF- $\beta$ signaling is impaired in the gastrointestinal (GI) tract, gastric tumors arise consequent of a reinvigorated, robust and chronic Th1 pro-inflammatory immune response to luminal bacteria. This inflammatory milieu leads to elevated levels of carcinogenic reactive oxygen species that repeatedly induce epithelial cell genomic damage promoting tumor initiation and tumor evolution [82-84]. The direct mechanisms by which TGF- $\beta$ mediates this tumor suppressive role have only recently been brought into the light and in so doing further illustrate the power of needing to understand TGF- $\beta$ signaling in the tissue context, with the study of mucosal borders such as the intestine, leading the field.

At the mucosal borders in the intestine and lung, TGF- $\beta$ is generated by innate immune cell (i.e., dendritic cells, monocytes) sampling of the luminal bacterial microenvironment [85-87]. The resulting TGF- $\beta$ signals to T cells, instigating upregulation of the transcription factor ROR $\gamma \mathrm{t}[88,89]$, to generate yet another distinct CD4+ helper T cell subset, Th17s. ROR $\gamma \mathrm{t}$ in Th17s induces the production of cytokines interleukin-17 (IL-17) and interleukin-22 (IL-22), and as an exquisite example of immune cell-epithelial cell crosstalk, IL-17 and IL-22 stimulate receptors on mucosal epithelial cells promoting epithelial border functionality. Specifically, this TGF- $\beta$-mediated cellular crosstalk results in epithelial stem cell maintenance, enhancement of epithelial cell junction integrity, and epithelial cell secretion of mucins and defensin production [85,87]. All of these mechanisms within the mucosal organ barricade against bacterial activation of Th1 immune cells preventing the instigation of the tissue-destructive and tumor initiating pro-inflammatory cycle.

While not classically considered a mucosal organ, the mammary gland displays several mucosal characteristics, especially during lactation and involution. Like the lung and gastrointestinal tract that excrete lipid rich mucus, the lactating mammary gland becomes an excretory organ expressing lipid rich milk. Furthermore, immunoglobulin A (IgA) antibodies and the IgA antibody secreting B cells, known to constitutively populate the GI tract and lung, are uniquely enriched in the mammary gland during lactation and early involution $[90,91]$. A hallmark feature of a mucosal organ is the role that organ plays as an interface between the outside environment and the inner tissue of the body. During lactation, through the nipple aperture and infant suckling, bacteria routinely interface with luminal epithelial cells, which must serve a barrier function to prevent systemic infection. Lastly, and most relevant to this discussion of TGF- $\beta$ biology, the TGF- $\beta$ driven Th17 immune milieu dominates the GI and pulmonary homeostatic state. Consistent with this mucosal characteristic, within hours of bacterial introduction into the duct of lactating ruminants, robust increases of IL-17 and IL-22 are observed [92]. This rapid exacerbation of Th17 cytokines strongly suggests a steady state presence of differentiated Th17 cells in the mammary gland during this developmental window. However, identification of Th17 cells themselves has yet to be reported in the lactating or involuting mammary gland in rodents or humans. Apart from this homeostatic and anti-Th1 induced cancer initiation role at mucosal surfaces, M2, Th2, and Th17 cells work alongside other cell types such as fibroblasts to integrate tissue-level TGF- $\beta$ signaling $[93,94]$. The TGF- $\beta$ mediated roles in fibroblasts also carry with them duplicitous implications for cancer biology. 


\section{The Role of TGF- $\beta$ in Tissue Repair and Remodeling}

As discussed above, TGF- $\beta$ mediates key events in the early stages of involution including cell death and early immune infiltration and immunosuppression. A later step of involution includes the concerted action of TGF- $\beta$ to bring about tissue repair and remodeling, with fibroblasts being logically implicated given their well described function in cutaneous wound healing. Fibroblasts are cells of mesenchymal origin found in all tissues, where they support epithelium, in part, by secreting the ECM compartment of the tissue. Under homeostatic conditions fibroblasts proliferate very slowly, if at all, and are involved in basal levels of ECM turnover [95]. If the tissue is damaged, fibroblasts become activated, including the upregulation of motility-, contractility-, ECM synthesis-, and growth factor secretion-programs, all of which facilitate tissue repair. A major regulator of fibroblast activation is the TGF- $\beta$ family of growth factors $[96,97]$. TGF- $\beta$ is normally sequestered in the ECM in an inactive state. Upon cutaneous tissue injury, various proteases including plasmin and matrix metalloproteinase 9 (MMP9) lead to cleavage of Latency Associated Peptide (LAP) resulting in the release of active TGF- $\beta$ into the local microenvironment [98-100]. Active TGF- $\beta$ can lead to the transcriptional up-regulation of genes involved in fibroblast activation. In the specific example of cutaneous wound healing, it has been shown that TGF- $\beta$ is necessary for development of the activated fibroblast, termed the myofibroblast. TGF- $\beta$-induced myofibroblasts express alpha smooth muscle actin $(\alpha-\mathrm{SMA})$, are motile, deposit collagen-rich ECM, and generate contractile force to facilitate wound closure [101-103]. Myofibroblasts under the guide of TGF- $\beta$, also deposit tenascin-C and the fibronectin (FN) splice variant ED-A FN, which are both specialized ECM proteins associated with adult tissue repair and embryonic development $[102,104]$. We next discuss how the latter stages of mammary gland involution share striking similarity with TGF- $\beta$-mediated cutaneous wound healing in the types of ECMs and ECM remodeling that occurs.

While it is not known if TGF- $\beta$ directs fibroblast-mediated tissue repair during mammary gland involution, similarities between TGF- $\beta$-mediated cutaneous wound healing and mammary gland involution are evident. For example fibrillar collagen, ED-A FN, FN fragments, matrix metalloproteinases (MMPs), and tenascin-C all increase during involution [43,44,48,105-107]. Altogether the similar composition and function of ECM proteins and proteases between TGF- $\beta$ orchestrated classical cutaneous wound healing and mammary gland involution support the notion that a hard-wired developmental process supports the return to homeostatic conditions in untransformed epithelium. However, these same wound healing programs and ECM depositions are known to trigger aggressive tumor behaviors.

\section{Dual Effects of ECM and Fibroblasts on Cancer Progression}

It has long been appreciated that stromal composition is similar between cancer and healing wounds [108]. We would add that normal mammary gland involution also shares similarities to these unique tissue microenvironments [43,44,48,105-107]. As discussed above, wound healing ECM supports untransformed epithelial cell survival and movement during healing, and this paradigm can be exploited by a tumor cell. For example, the de novo deposition of collagen I can literally serve as "tracks" by which cancer cells traffic, leading to local tumor cell invasion and eventual metastasis $[109,110]$. Importantly, this means that the same biological mechanism can lead to disparate outcomes based on the transformation state of the epithelium, and supports the idea that the activated fibroblast phenotype can be parlayed into a tumor-promotional function when transformed epithelium is present (Figure 2C). However, fibroblasts are no exception to the duality of TGF- $\beta$ effects, as TGF- $\beta$ has also been shown to be necessary for fibroblast mediated tumor suppression.

The finding that loss of TGF- $\beta$ stimulation in fibroblasts supports tumors appears contrary to the known tumor promotional role of activated fibroblasts. Specifically, it has been shown that deletion of Tgfbr 2 in fibroblasts, and thus downstream TGF- $\beta$ signaling, induces paracrine hepatocyte growth factor (HGF) signaling and promotion of mammary carcinogenesis [111]. Similarly, other studies in a mouse mammary tumor virus driven Polyoma Virus middle T antigen (MMTV-PyVmT) tumor model 
have shown that loss of one Tgfbr2 allele in fibroblasts can induce early tumor onset and increased metastasis [112]. Further, it has been shown in vitro, in a fibroblast specific protein (FSP) driven Tgfbr2 $\mathrm{KO}\left(\mathrm{Tgfbr} 2^{\mathrm{FSPKO}}\right)$ model, the fibroblasts upregulate SDF1 [112], which is a molecule that promotes tumor progression directly by inducing tumor cell proliferation and migration, and indirectly via induction of immunosuppressive myeloid-derived suppressor cells [113-116]. Tgfbr $2^{\mathrm{FSPKO}}$ tissue also has increased production of various inflammatory mediators including inducible nitrogen oxide synthase, cyclooxygenase-2 (COX2), and NFKB in both epithelial and stromal cells [117]. In accordance with these observations, mice with $T g f b r 2^{\mathrm{FSPKO}}$ fibroblasts had an increased infiltration of immunosuppressive myeloid-derived suppressor cells and Th17 cells [117], implicating fibroblasts in modulating the immune milieu via TGF- $\beta$.

A striking observation of the studies described above is that Tgfbr $2 \mathrm{KO}$ fibroblasts exhibit a loss of a TGF- $\beta$ negative feed-back loop, overproducing TGF- $\beta$ in response to a loss of TGF- $\beta$ R signaling. This results in increased TGF- $\beta$ within the tissue that can influence neighboring tumor cells and immune cells directly, elevating tumor aggressiveness [118]. Of note, if these experiments had been performed in simple cell culture systems, or in the absence of either relevant epithelial or immune cell populations, the powerful observation that fibroblasts lacking TGF- $\beta$ R make more TGF- $\beta$ would never have been made. In the tissue context of the conditional KO system, the data suggest fibroblasts have a unique and central role in both sensing and modulating the levels of TGF- $\beta$ in the whole tissue system. Therefore, fibroblast TGF- $\beta$ signaling may occupy a central role in the instigation of the TGF- $\beta$ paradox.

\section{Implications/Next Steps for Therapy}

It has been proposed that in cancers where the TGF- $\beta$ signaling pathway is mutated, yet TGF- $\beta$ inhibitors are effective, that this may be due to tumor extrinsic targeting of the fibroblasts and/or the immune milieu [31]. Yet, in the context of the immune system, TGF- $\beta$ inhibitors would also be predicted to enhanced tumor initiation consequent of elevating the pro-inflammatory and pro-carcinogenic Th1 programs. Hence, from an immunologic perspective, TGF- $\beta$ inhibitors are likely not appropriate for use as a preventative measure. Somewhere along the continuum of tumor development, blocking TGF- $\beta$ is expected to reduce immunosuppression providing a reduction in existing tumor burden, however when during cancer progression anti-TGF- $\beta$ therapy would be detrimental or helpful remains unknown, making this approach risky. Similarly, within the isolated context of the tumor-associated fibroblast, TGF- $\beta$ inhibition is expected to decrease tumor supportive fibrotic stroma. However, we know that fibroblasts lacking the ability to respond to TGF- $\beta$ (Tgfbr 2 $\mathrm{KO})$ produce more pro-tumorigenic cytokines. Thus, even though an anti-TGF- $\beta$ effect may result in the fibroblast itself becoming less pro-tumorigenic, the global effect may be enhanced tumor cell progression, the undesired effect. These evidences outline the fragile nature of direct TGF- $\beta$ inhibition as related to the microenvironment.

Although there may be success with direct TGF- $\beta$ inhibition, we propose the employment of alternative strategies. One potential approach is via targeting processes that TGF- $\beta$ drives that are pro-tumor without directly inhibiting TGF- $\beta$, such as the use of cyclooxygenase (COX) inhibitors. TGF- $\beta$ has been shown to directly upregulate COX2 expression on multiple cell subtypes and many of the pathological features of TGF- $\beta$ observed in the tumor microenvironment are at least partially attributable to the presence of the COX2 product prostaglandin E2 (PGE2) [63,119-123]. COX inhibitors have been shown to dampen the immunosuppressive pro-tumor behavior of various immune cells $[124,125]$, and also decrease fibrotic pro-tumor stroma $[44,48,80,81,126]$ and could be explored further as an approach to inhibit pro-tumorigenic aspects of TGF- $\beta$ signaling while preserving anti-tumor attributes (Figure 4). 


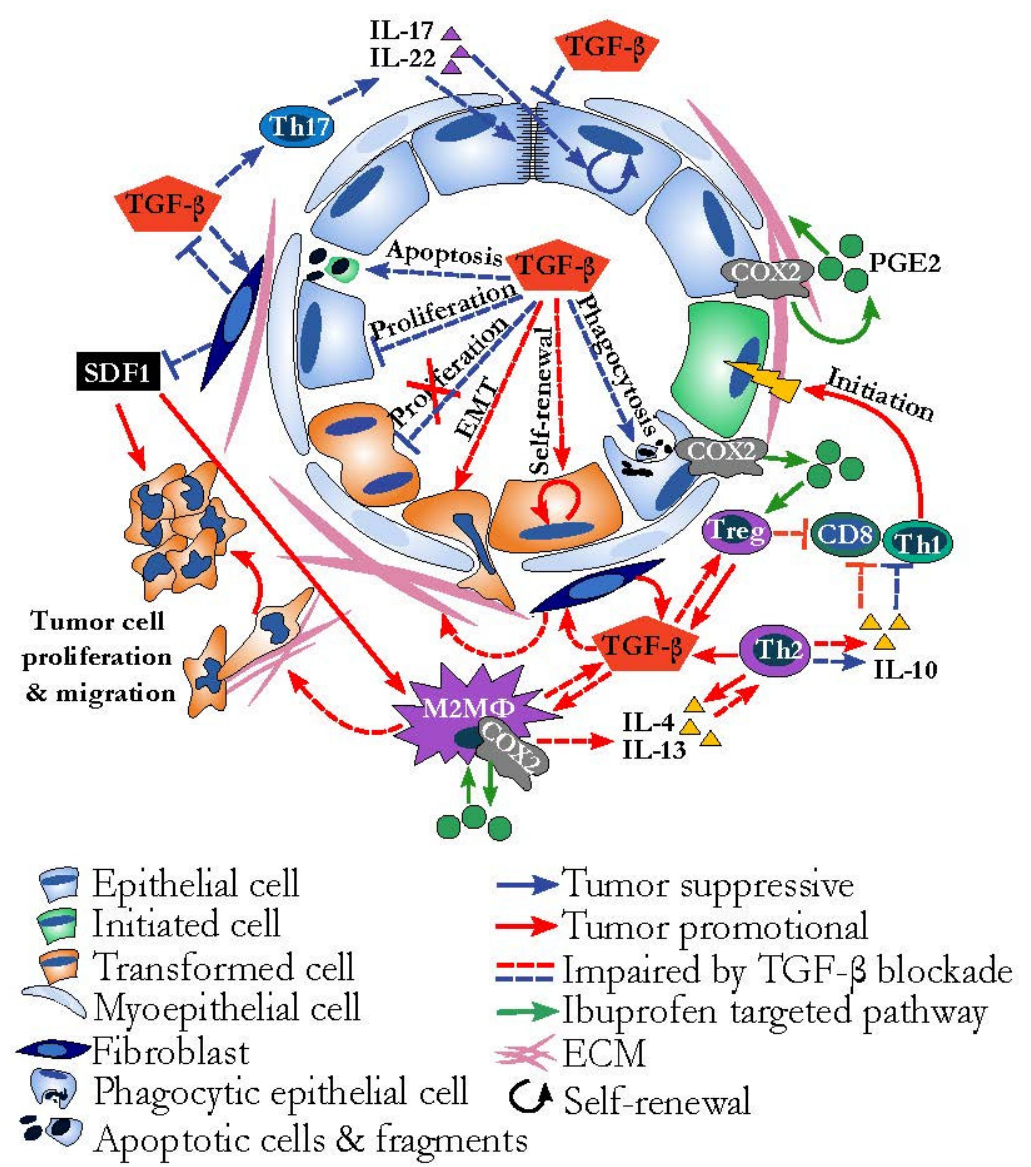

Figure 4. Tissue-level TGF- $\beta$ signaling and implications for TGF- $\beta$ targeted therapy. TGF- $\beta$ can simultaneously mediate pro-tumor (red arrows) and anti-tumor (blue arrows) activities, depending on responding cell type. The effect of an anti-TGF- $\beta$ therapy would be expected to result in both dampened pro-tumor (red dotted lines) and dampened anti-tumor (blue dotted lines) activities of TGF- $\beta$, resulting in mixed tumor outcome. Anti-tumor effects of blocking TGF- $\beta$ are decreased tumor cell proliferation, M2 polarization, and extracellular matrix (ECM) deposition, and pro-tumorigenic effects include pro-inflammatory tumor initiation (green cell) and enhanced fibroblast production of pro-tumor stromal cell-derived factor 1 (SDF1) and TGF- $\beta$. An alternative strategy to direct TGF- $\beta$ targeting may be to target downstream effectors. TGF- $\beta$ is known to induce cyclooxygenase- 2 (COX2) and subsequent prostaglandin E2 (PGE2) (green circle) production by a number of cell types. Targeting COX2 activity (processes depicted by green arrows) targets pathways in the established cancer environment that may have more uni-directionally pro-tumor effects, such as M2/Th2 polarization and ECM deposition, without impairing TGF- $\beta$ mediated tumor suppressive functions.

In considering where to utilize these hypothetical therapeutic approaches generated by insight from the tissue microenvironmental model, it seems logical to start with tumor environments that employ TGF- $\beta$ mediated processes. We therefore return our attention to breast cancer and a unique subpopulation of patients who are diagnosed with breast cancer as young women in their reproductive years. Pregnancy associated breast cancer (PABC) encapsulates a younger demographic of breast cancer patients whose breast cancer is diagnosed during pregnancy or within 5 years of having given birth to a child [49]. Amongst this group, it has been determined that patients diagnosed with breast cancer within 5 years of last having a child, but not during pregnancy, have much poorer prognosis, equivalent or worse than the most deadly subtype of breast cancer, triple negative breast cancer $[127,128]$. This poor prognostic breast cancer is referred to as postpartum breast cancer. Through insights gleaned from multiple rodent models of postpartum breast cancer, it has been proposed that the poorer outcomes 
experienced by postpartum patients is consequent of indolent tumors being promoted by breast involution, which, as described above, is under the control of TGF- $\beta$. Further, in these rodent models of postpartum breast cancer, COX-2 inhibition reduces involution instigated tumor promotion through a reduction in many of the TGF- $\beta$ mediated processes we have described $[48,80]$ and offers an example of a novel, targeted and efficacious therapeutic approach that might be adopted for a patient cohort for whom standard of care is poorly effective.

Many biological processes mediated by TGF- $\beta$ have been implicated in both cancer suppression and promotion, highlighting TGF- $\beta$ 's central position in the cancer field. With the current depth of mechanistic understanding, we advocate for shifting the focus of TGF- $\beta$ mediated research to include not only other cellular actors from the microenvironment but also utilizing relevant microenvironments themselves where all the actors of TGF- $\beta$ are present. This would allow researchers to quantify how the diverse functionalities of TGF- $\beta$ within different cell subsets compete or reinforce one another to impact cancer outcomes. Furthermore, we encourage investigation downstream of TGF- $\beta$ signaling to elucidate specific processes dependent upon TGF- $\beta$, as downstream targets might bias treatment more powerfully towards anti-cancer responses without targeting TGF- $\beta$ directly. In summary, by utilizing the developmental window of mammary gland involution, we have been able to investigate many of the various roles of TGF- $\beta$ and have concluded that the paradox of TGF- $\beta$ is the unresolvable reality of a complex interactive microenvironment. Moving forward we must integrate this complex reality into therapeutic strategies to more predictably improve patient outcomes.

Acknowledgments: This work was supported by funds from the Knight Cancer Institute, Oregon Health \& Science University, sponsored graduate student stipend (to Q. Guo), NIH pre-doctoral fellowship F31 (1F31CA196052-02 to C. Betts), the Department of Defense (W81XWH-11-1-0776 to P. Schedin), NIH/National Cancer Institute (1R01CA169175 to P. Schedin and V. Borges) and the Kay Yow Cancer Fund to P. Schedin. We thank Holly Martinson, for initiating and performing the seminal studies describing immune cells in the mammary gland during involution. We thank Weston Anderson for help with manuscript composition and editing.

Author Contributions: Q.G., C.B. and N.P. were equally responsible for researching references, manuscript composition and figure drafting. P.S. framed, supervised, and edited the work. E.M. drafted, created and revised the figures. All authors contributed to manuscript editing and proofreading.

Conflicts of Interest: The authors declare that they have no conflicts of interest. The founding sponsors had no role in writing of the manuscript.

\section{References}

1. Tian, M.; Schiemann, W.P. The tgf-beta paradox in human cancer: An update. Future Oncol. 2009, 5, $259-271$. [CrossRef] [PubMed]

2. Jakowlew, S.B. Transforming growth factor-beta in cancer and metastasis. Cancer Metastasis Rev. 2006, 25, 435-457. [CrossRef] [PubMed]

3. Moses, H.L. TGF-beta regulation of epithelial cell proliferation. Mol. Reprod. Dev. 1992, 32, $179-184$. [CrossRef] [PubMed]

4. Li, M.O.; Wan, Y.Y.; Sanjabi, S.; Robertson, A.K.; Flavell, R.A. Transforming growth factor-beta regulation of immune responses. Annu. Rev. Immunol. 2006, 24, 99-146. [CrossRef] [PubMed]

5. Clark, R.A.; McCoy, G.A.; Folkvord, J.M.; McPherson, J.M. TGF-beta 1 stimulates cultured human fibroblasts to proliferate and produce tissue-like fibroplasia: A fibronectin matrix-dependent event. J. Cell. Physiol. 1997, 170, 69-80. [CrossRef]

6. Nguyen, A.V.; Pollard, J.W. Transforming growth factor beta3 induces cell death during the first stage of mammary gland involution. Development 2000, 127, 3107-3118. [PubMed]

7. Fornetti, J.; Flanders, K.C.; Henson, P.M.; Tan, A.C.; Borges, V.F.; Schedin, P. Mammary epithelial cell phagocytosis downstream of TGF-beta3 is characterized by adherens junction reorganization. Cell Death Differ. 2016, 23, 185-196. [CrossRef] [PubMed]

8. Verrecchia, F.; Mauviel, A. Transforming growth factor-beta signaling through the smad pathway: Role in extracellular matrix gene expression and regulation. J. Invest. Dermatol. 2002, 118, 211-215. [CrossRef] [PubMed] 
9. Xu, J.; Lamouille, S.; Derynck, R. TGF-beta-induced epithelial to mesenchymal transition. Cell Res. 2009, 19, 156-172. [CrossRef] [PubMed]

10. Shi, Y.; Massague, J. Mechanisms of TGF-beta signaling from cell membrane to the nucleus. Cell 2003, 113, 685-700. [CrossRef]

11. Zhang, Y.E. Non-smad pathways in tgf-beta signaling. Cell Res. 2009, 19, 128-139. [CrossRef] [PubMed]

12. Hata, A.; Chen, Y.G. TGF-beta signaling from receptors to smads. Cold Spring Harb. Perspect. Biol. 2016, 8, 1-31. [CrossRef] [PubMed]

13. Biswas, T.; Gu, X.; Yang, J.; Ellies, L.G.; Sun, L.Z. Attenuation of tgf-beta signaling supports tumor progression of a mesenchymal-like mammary tumor cell line in a syngeneic murine model. Cancer Lett. 2014, 346, 129-138. [CrossRef] [PubMed]

14. Rotello, R.J.; Lieberman, R.C.; Purchio, A.F.; Gerschenson, L.E. Coordinated regulation of apoptosis and cell proliferation by transforming growth factor beta 1 in cultured uterine epithelial cells. Proc. Natl. Acad. Sci. USA 1991, 88, 3412-3415. [CrossRef] [PubMed]

15. Hocevar, B.A.; Howe, P.H. Mechanisms of tgf-beta-induced cell cycle arrest. Miner. Electrolyte Metab. 1998, 24, 131-135. [CrossRef] [PubMed]

16. Jang, C.W.; Chen, C.H.; Chen, C.C.; Chen, J.Y.; Su, Y.H.; Chen, R.H. TGF-beta induces apoptosis through smad-mediated expression of dap-kinase. Nat. Cell Biol. 2002, 4, 51-58. [CrossRef] [PubMed]

17. Cohen, O.; Inbal, B.; Kissil, J.L.; Raveh, T.; Berissi, H.; Spivak-Kroizaman, T.; Feinstein, E.; Kimchi, A. Dap-kinase participates in tnf-alpha- and fas-induced apoptosis and its function requires the death domain. J. Cell Biol. 1999, 146, 141-148. [CrossRef] [PubMed]

18. Gozuacik, D.; Bialik, S.; Raveh, T.; Mitou, G.; Shohat, G.; Sabanay, H.; Mizushima, N.; Yoshimori, T.; Kimchi, A. Dap-kinase is a mediator of endoplasmic reticulum stress-induced caspase activation and autophagic cell death. Cell Death Differ. 2008, 15, 1875-1886. [CrossRef] [PubMed]

19. Oberhammer, F.A.; Pavelka, M.; Sharma, S.; Tiefenbacher, R.; Purchio, A.F.; Bursch, W.; Schulte-Hermann, R. Induction of apoptosis in cultured hepatocytes and in regressing liver by transforming growth factor beta 1. Proc. Natl. Acad. Sci. U. S. A. 1992, 89, 5408-5412. [CrossRef] [PubMed]

20. Mithani, S.K.; Balch, G.C.; Shiou, S.R.; Whitehead, R.H.; Datta, P.K.; Beauchamp, R.D. Smad3 has a critical role in TGF-beta-mediated growth inhibition and apoptosis in colonic epithelial cells. J. Surg. Res. 2004, 117, 296-305. [CrossRef]

21. Kolek, O.; Gajkowska, B.; Godlewski, M.M.; Motyl, T. Molecular mechanism of tgf-beta1-induced apoptosis in hc11 mouse mammary epithelial cells (mec). Cell Mol. Biol. 2001, 47, OL197-208. [PubMed]

22. Engle, S.J.; Hoying, J.B.; Boivin, G.P.; Ormsby, I.; Gartside, P.S.; Doetschman, T. Transforming growth factor beta1 suppresses nonmetastatic colon cancer at an early stage of tumorigenesis. Cancer Res. 1999, 59, 3379-3386. [PubMed]

23. Matsushita, M.; Matsuzaki, K.; Date, M.; Watanabe, T.; Shibano, K.; Nakagawa, T.; Yanagitani, S.; Amoh, Y.; Takemoto, H.; Ogata, N.; et al. Down-regulation of tgf-beta receptors in human colorectal cancer: Implications for cancer development. Br. J. Cancer 1999, 80, 194-205. [CrossRef] [PubMed]

24. Fleming, N.I.; Jorissen, R.N.; Mouradov, D.; Christie, M.; Sakthianandeswaren, A.; Palmieri, M.; Day, F.; Li, S.; Tsui, C.; Lipton, L.; et al. Smad2, smad3 and smad4 mutations in colorectal cancer. Cancer Res. 2013, 73, 725-735. [CrossRef] [PubMed]

25. Zhang, Y.; Musci, T.; Derynck, R. The tumor suppressor smad4/dpc 4 as a central mediator of smad function. Curr. Biol. 1997, 7, 270-276. [CrossRef]

26. Bhowmick, N.A.; Ghiassi, M.; Bakin, A.; Aakre, M.; Lundquist, C.A.; Engel, M.E.; Arteaga, C.L.; Moses, H.L. Transforming growth factor-beta1 mediates epithelial to mesenchymal transdifferentiation through a rhoa-dependent mechanism. Mol. Biol. Cell 2001, 12, 27-36. [CrossRef] [PubMed]

27. Pirozzi, G.; Tirino, V.; Camerlingo, R.; Franco, R.; La Rocca, A.; Liguori, E.; Martucci, N.; Paino, F.; Normanno, N.; Rocco, G. Epithelial to mesenchymal transition by tgfbeta-1 induction increases stemness characteristics in primary non small cell lung cancer cell line. PloS ONE 2011, 6, e21548. [CrossRef] [PubMed]

28. Oshimori, N.; Oristian, D.; Fuchs, E. TGF-beta promotes heterogeneity and drug resistance in squamous cell carcinoma. Cell 2015, 160, 963-976. [CrossRef] [PubMed]

29. Welch, D.R.; Fabra, A.; Nakajima, M. Transforming growth factor beta stimulates mammary adenocarcinoma cell invasion and metastatic potential. Proc. Natl. Acad. Sci. U. S. A. 1990, 87, 7678-7682. [CrossRef] [PubMed] 
30. Herbertz, S.; Sawyer, J.S.; Stauber, A.J.; Gueorguieva, I.; Driscoll, K.E.; Estrem, S.T.; Cleverly, A.L.; Desaiah, D.; Guba, S.C.; Benhadji, K.A.; et al. Clinical development of galunisertib (ly2157299 monohydrate), a small molecule inhibitor of transforming growth factor-beta signaling pathway. Drug Des. Devel. Ther. 2015, 9, 4479-4499. [PubMed]

31. Neuzillet, C.; Tijeras-Raballand, A.; Cohen, R.; Cros, J.; Faivre, S.; Raymond, E.; de Gramont, A. Targeting the tgfbeta pathway for cancer therapy. Pharmacol. Ther. 2015, 147, 22-31. [CrossRef] [PubMed]

32. Connolly, E.C.; Freimuth, J.; Akhurst, R.J. Complexities of TGF-beta targeted cancer therapy. Int. J. Biol. Sci. 2012, 8, 964-978. [CrossRef] [PubMed]

33. Giaccone, G.; Bazhenova, L.A.; Nemunaitis, J.; Tan, M.; Juhasz, E.; Ramlau, R.; van den Heuvel, M.M.; Lal, R.; Kloecker, G.H.; Eaton, K.D.; et al. A phase iii study of belagenpumatucel-1, an allogeneic tumour cell vaccine, as maintenance therapy for non-small cell lung cancer. Eur. J. Cancer 2015, 51, 2321-2329. [CrossRef] [PubMed]

34. Cohn, A.; Lahn, M.M.; Williams, K.E.; Cleverly, A.L.; Pitou, C.; Kadam, S.K.; Farmen, M.W.; Desaiah, D.; Raju, R.; Conkling, P.; et al. A phase i dose-escalation study to a predefined dose of a transforming growth factor-beta1 monoclonal antibody (tbetam1) in patients with metastatic cancer. Int. J. Oncol. 2014, 45, 2221-2231.

35. Macias, H.; Hinck, L. Mammary gland development. Wiley Interdiscip. Rev. Dev. Biol. 2012, 1, $533-557$. [CrossRef] [PubMed]

36. Quarrie, L.H.; Addey, C.V.; Wilde, C.J. Programmed cell death during mammary tissue involution induced by weaning, litter removal, and milk stasis. J. Cell. Physiol. 1996, 168, 559-569. [CrossRef]

37. Lund, L.R.; Romer, J.; Thomasset, N.; Solberg, H.; Pyke, C.; Bissell, M.J.; Dano, K.; Werb, Z. Two distinct phases of apoptosis in mammary gland involution: Proteinase-independent and -dependent pathways. Development 1996, 122, 181-193. [PubMed]

38. Strange, R.; Li, F.; Saurer, S.; Burkhardt, A.; Friis, R.R. Apoptotic cell death and tissue remodelling during mouse mammary gland involution. Development 1992, 115, 49-58. [PubMed]

39. Stein, T.; Morris, J.S.; Davies, C.R.; Weber-Hall, S.J.; Duffy, M.A.; Heath, V.J.; Bell, A.K.; Ferrier, R.K.; Sandilands, G.P.; Gusterson, B.A. Involution of the mouse mammary gland is associated with an immune cascade and an acute-phase response, involving lbp, cd14 and stat3. Breast Cancer Res. 2004, 6, R75-91. [CrossRef] [PubMed]

40. Clarkson, R.W.; Wayland, M.T.; Lee, J.; Freeman, T.; Watson, C.J. Gene expression profiling of mammary gland development reveals putative roles for death receptors and immune mediators in post-lactational regression. Breast Cancer Res. 2004, 6, R92-109. [CrossRef] [PubMed]

41. Walker, N.I.; Bennett, R.E.; Kerr, J.F. Cell death by apoptosis during involution of the lactating breast in mice and rats. Am. J. Anat. 1989, 185, 19-32. [CrossRef] [PubMed]

42. Alexander, C.M.; Selvarajan, S.; Mudgett, J.; Werb, Z. Stromelysin-1 regulates adipogenesis during mammary gland involution. J. Cell Biol. 2001, 152, 693-703. [CrossRef] [PubMed]

43. O’Brien, J.; Lyons, T.; Monks, J.; Lucia, M.S.; Wilson, R.S.; Hines, L.; Man, Y.G.; Borges, V.; Schedin, P. Alternatively activated macrophages and collagen remodeling characterize the postpartum involuting mammary gland across species. Am. J. Pathol. 2010, 176, 1241-1255. [CrossRef] [PubMed]

44. O’Brien, J.H.; Vanderlinden, L.A.; Schedin, P.J.; Hansen, K.C. Rat mammary extracellular matrix composition and response to ibuprofen treatment during postpartum involution by differential gelc-ms/ms analysis. J. Proteome Res. 2012, 11, 4894-4905. [CrossRef] [PubMed]

45. Martinson, H.A.; Jindal, S.; Durand-Rougely, C.; Borges, V.F.; Schedin, P. Wound healing-like immune program facilitates postpartum mammary gland involution and tumor progression. Int. J. Cancer 2015, 136, 1803-1813. [CrossRef] [PubMed]

46. Meier-Abt, F.; Brinkhaus, H.; Bentires-Alj, M. Early but not late pregnancy induces lifelong reductions in the proportion of mammary progesterone sensing cells and epithelial wnt signaling. Breast Cancer Res. 2014, 16, 402. [CrossRef] [PubMed]

47. Fornetti, J.; Martinson, H.A.; Betts, C.B.; Lyons, T.R.; Jindal, S.; Guo, Q.; Coussens, L.M.; Borges, V.F.; Schedin, P. Mammary gland involution as an immunotherapeutic target for postpartum breast cancer. J. Mammary Gland Biol. Neoplasia 2014, 19, 213-228. [CrossRef] [PubMed] 
48. Lyons, T.R.; O’Brien, J.; Borges, V.F.; Conklin, M.W.; Keely, P.J.; Eliceiri, K.W.; Marusyk, A.; Tan, A.C.; Schedin, P. Postpartum mammary gland involution drives progression of ductal carcinoma in situ through collagen and cox-2. Nat. Med. 2011, 17, 1109-1115. [CrossRef] [PubMed]

49. Schedin, P. Pregnancy-associated breast cancer and metastasis. Nat. Rev. Cancer 2006, 6, 281-291. [CrossRef] [PubMed]

50. Sargeant, T.J.; Lloyd-Lewis, B.; Resemann, H.K.; Ramos-Montoya, A.; Skepper, J.; Watson, C.J. Stat3 controls cell death during mammary gland involution by regulating uptake of milk fat globules and lysosomal membrane permeabilization. Nat. Cell Biol. 2014, 16, 1057-1068. [CrossRef] [PubMed]

51. Marti, A.; Ritter, P.M.; Jager, R.; Lazar, H.; Baltzer, A.; Schenkel, J.; Declercq, W.; Vandenabeele, P.; Jaggi, R. Mouse mammary gland involution is associated with cytochrome c release and caspase activation. Mech. Dev. 2001, 104, 89-98. [CrossRef]

52. Sakamoto, K.; Wehde, B.L.; Yoo, K.H.; Kim, T.; Rajbhandari, N.; Shin, H.Y.; Triplett, A.A.; Radler, P.D.; Schuler, F.; Villunger, A.; et al. Janus kinase 1 is essential for inflammatory cytokine signaling and mammary gland remodeling. Mol. Cell. Biol. 2016, 36, 1673-1690. [CrossRef] [PubMed]

53. Schere-Levy, C.; Buggiano, V.; Quaglino, A.; Gattelli, A.; Cirio, M.C.; Piazzon, I.; Vanzulli, S.; Kordon, E.C. Leukemia inhibitory factor induces apoptosis of the mammary epithelial cells and participates in mouse mammary gland involution. Exp. Cell Res. 2003, 282, 35-47. [CrossRef] [PubMed]

54. Bagci, H.; Laurin, M.; Huber, J.; Muller, W.J.; Cote, J.F. Impaired cell death and mammary gland involution in the absence of dock1 and rac1 signaling. Cell Death Dis. 2014, 5, e1375. [CrossRef] [PubMed]

55. Baxter, F.O.; Came, P.J.; Abell, K.; Kedjouar, B.; Huth, M.; Rajewsky, K.; Pasparakis, M.; Watson, C.J. Ikkbeta/2 induces tweak and apoptosis in mammary epithelial cells. Development 2006, 133, 3485-3494. [CrossRef] [PubMed]

56. Llobet-Navas, D.; Rodriguez-Barrueco, R.; Castro, V.; Ugalde, A.P.; Sumazin, P.; Jacob-Sendler, D.; Demircan, B.; Castillo-Martin, M.; Putcha, P.; Marshall, N.; et al. The mir-424(322)/503 cluster orchestrates remodeling of the epithelium in the involuting mammary gland. Genes Dev. 2014, 28, 765-782. [CrossRef] [PubMed]

57. Llobet-Navas, D.; Rodriguez-Barrueco, R.; de la Iglesia-Vicente, J.; Olivan, M.; Castro, V.; Saucedo-Cuevas, L.; Marshall, N.; Putcha, P.; Castillo-Martin, M.; Bardot, E.; et al. The microrna 424/503 cluster reduces cdc25a expression during cell cycle arrest imposed by transforming growth factor beta in mammary epithelial cells. Mol. Cell. Biol. 2014, 34, 4216-4231. [CrossRef] [PubMed]

58. Dunker, N.; Krieglstein, K. Targeted mutations of transforming growth factor-beta genes reveal important roles in mouse development and adult homeostasis. Eur. J. Biochem. 2000, 267, 6982-6988. [CrossRef] [PubMed]

59. Kaartinen, V.; Voncken, J.W.; Shuler, C.; Warburton, D.; Bu, D.; Heisterkamp, N.; Groffen, J. Abnormal lung development and cleft palate in mice lacking tgf-beta 3 indicates defects of epithelial-mesenchymal interaction. Nat. Genet. 1995, 11, 415-421. [CrossRef] [PubMed]

60. Bierie, B.; Gorska, A.E.; Stover, D.G.; Moses, H.L. TGF-beta promotes cell death and suppresses lactation during the second stage of mammary involution. J. Cell. Physiol. 2009, 219, 57-68. [CrossRef] [PubMed]

61. Monks, J.; Smith-Steinhart, C.; Kruk, E.R.; Fadok, V.A.; Henson, P.M. Epithelial cells remove apoptotic epithelial cells during post-lactation involution of the mouse mammary gland. Biol. Reprod. 2008, 78, 586-594. [CrossRef] [PubMed]

62. Sheu, S.J.; Sakamoto, T.; Osusky, R.; Wang, H.M.; Ogden, T.E.; Ryan, S.J.; Hinton, D.R.; Gopalakrishna, R. Transforming growth factor-beta regulates human retinal pigment epithelial cell phagocytosis by influencing a protein kinase c-dependent pathway. Graefe's Arch. Clin. Exp. Ophthalmol. 1994, 232, 695-701. [CrossRef]

63. Maderna, P.; Godson, C. Phagocytosis of apoptotic cells and the resolution of inflammation. Biochim. Biophys. Acta 2003, 1639, 141-151. [CrossRef] [PubMed]

64. Fadok, V.A.; Bratton, D.L.; Konowal, A.; Freed, P.W.; Westcott, J.Y.; Henson, P.M. Macrophages that have ingested apoptotic cells in vitro inhibit proinflammatory cytokine production through autocrine/paracrine mechanisms involving TGF-beta, pge2, and paf. J. Clin. Investig. 1998, 101, 890-898. [CrossRef] [PubMed]

65. Huynh, M.L.; Fadok, V.A.; Henson, P.M. Phosphatidylserine-dependent ingestion of apoptotic cells promotes TGF-beta1 secretion and the resolution of inflammation. J. Clin. Investig. 2002, 109, 41-50. [CrossRef] [PubMed] 
66. Xiong, W.; Frasch, S.C.; Thomas, S.M.; Bratton, D.L.; Henson, P.M. Induction of tgf-beta1 synthesis by macrophages in response to apoptotic cells requires activation of the scavenger receptor cd36. PloS ONE 2013, 8, e72772. [CrossRef] [PubMed]

67. O'Brien, J.; Martinson, H.; Durand-Rougely, C.; Schedin, P. Macrophages are crucial for epithelial cell death and adipocyte repopulation during mammary gland involution. Development 2012, 139, 269-275. [CrossRef] [PubMed]

68. Peng, Y.; Laouar, Y.; Li, M.O.; Green, E.A.; Flavell, R.A. TGF-beta regulates in vivo expansion of foxp3-expressing cd4+cd25+ regulatory $\mathrm{T}$ cells responsible for protection against diabetes. Proc. Natl. Acad. Sci. USA 2004, 101, 4572-4577. [CrossRef] [PubMed]

69. Gorelik, L.; Flavell, R.A. Abrogation of tgfbeta signaling in T cells leads to spontaneous $\mathrm{t}$ cell differentiation and autoimmune disease. Immunity 2000, 12, 171-181. [CrossRef]

70. Wahl, S.M.; Hunt, D.A.; Wakefield, L.M.; McCartney-Francis, N.; Wahl, L.M.; Roberts, A.B.; Sporn, M.B. Transforming growth factor type beta induces monocyte chemotaxis and growth factor production. Proc. Natl. Acad. Sci. U. S. A. 1987, 84, 5788-5792. [CrossRef] [PubMed]

71. Turley, J.M.; Falk, L.A.; Ruscetti, F.W.; Kasper, J.J.; Francomano, T.; Fu, T.; Bang, O.S.; Birchenall-Roberts, M.C. Transforming growth factor beta 1 functions in monocytic differentiation of hematopoietic cells through autocrine and paracrine mechanisms. Cell Growth Differ. 1996, 7, 1535-1544. [PubMed]

72. Gong, D.; Shi, W.; Yi, S.J.; Chen, H.; Groffen, J.; Heisterkamp, N. Tgfbeta signaling plays a critical role in promoting alternative macrophage activation. BMC Immunol. 2012, 13, 31. [CrossRef] [PubMed]

73. Stein, M.; Keshav, S.; Harris, N.; Gordon, S. Interleukin 4 potently enhances murine macrophage mannose receptor activity: A marker of alternative immunologic macrophage activation. J. Exp. Med. 1992, 176, 287-292. [CrossRef] [PubMed]

74. Bonecchi, R.; Sozzani, S.; Stine, J.T.; Luini, W.; D'mico, G.; Allavena, P.; Chantry, D.; Mantovani, A. Divergent effects of interleukin-4 and interferon-gamma on macrophage-derived chemokine production: An amplification circuit of polarized T helper 2 responses. Blood 1998, 92, 2668-2671. [PubMed]

75. Zheng, W.; Flavell, R.A. The transcription factor gata-3 is necessary and sufficient for th2 cytokine gene expression in cd4 T cells. Cell 1997, 89, 587-596. [CrossRef]

76. Kanhere, A.; Hertweck, A.; Bhatia, U.; Gokmen, M.R.; Perucha, E.; Jackson, I.; Lord, G.M.; Jenner, R.G. T-bet and gata 3 orchestrate th1 and th2 differentiation through lineage-specific targeting of distal regulatory elements. Nat. Commun. 2012, 3, 1268. [CrossRef] [PubMed]

77. Stanford, J.C.; Young, C.; Hicks, D.; Owens, P.; Williams, A.; Vaught, D.B.; Morrison, M.M.; Lim, J.; Williams, M.; Brantley-Sieders, D.M.; et al. Efferocytosis produces a prometastatic landscape during postpartum mammary gland involution. J. Clin. Investig. 2014, 124, 4737-4752. [CrossRef] [PubMed]

78. Cools, N.; Van Tendeloo, V.F.; Smits, E.L.; Lenjou, M.; Nijs, G.; Van Bockstaele, D.R.; Berneman, Z.N.; Ponsaerts, P. Immunosuppression induced by immature dendritic cells is mediated by TGF-beta/IL-10 double-positive cd4+ regulatory T cells. J. Cell. Mol. Med. 2008, 12, 690-700. [CrossRef] [PubMed]

79. Ghiringhelli, F.; Puig, P.E.; Roux, S.; Parcellier, A.; Schmitt, E.; Solary, E.; Kroemer, G.; Martin, F.; Chauffert, B.; Zitvogel, L. Tumor cells convert immature myeloid dendritic cells into tgf-beta-secreting cells inducing cd4+cd25+ regulatory T cell proliferation. J. Exp. Med. 2005, 202, 919-929. [CrossRef] [PubMed]

80. Lyons, T.R.; Borges, V.F.; Betts, C.B.; Guo, Q.; Kapoor, P.; Martinson, H.A.; Jindal, S.; Schedin, P. Cyclooxygenase-2-dependent lymphangiogenesis promotes nodal metastasis of postpartum breast cancer. J. Clin. Investig. 2014, 124, 3901-3912. [CrossRef] [PubMed]

81. O’Brien, J.; Hansen, K.; Barkan, D.; Green, J.; Schedin, P.; O’Brien, J.; Hansen, K.; Barkan, D.; Green, J.; Schedin, P. Non-steroidal anti-inflammatory drugs target the pro-tumorigenic extracellular matrix of the postpartum mammary gland. Int. J. Dev. Biol. 2011, 55, 745-755. [CrossRef] [PubMed]

82. Engle, S.J.; Ormsby, I.; Pawlowski, S.; Boivin, G.P.; Croft, J.; Balish, E.; Doetschman, T. Elimination of colon cancer in germ-free transforming growth factor beta 1-deficient mice. Cancer Res. 2002, 62, 6362-6366. [PubMed]

83. Liu, J.Z.; Pezeshki, M.; Raffatellu, M. Th17 cytokines and host-pathogen interactions at the mucosa: Dichotomies of help and harm. Cytokine 2009, 48, 156-160. [CrossRef] [PubMed]

84. Kim, B.G.; Li, C.; Qiao, W.; Mamura, M.; Kasprzak, B.; Anver, M.; Wolfraim, L.; Hong, S.; Mushinski, E.; Potter, M.; et al. Smad4 signalling in T cells is required for suppression of gastrointestinal cancer. Nature 2006, 441, 1015-1019. [CrossRef] [PubMed] 
85. Atarashi, K.; Tanoue, T.; Ando, M.; Kamada, N.; Nagano, Y.; Narushima, S.; Suda, W.; Imaoka, A.; Setoyama, H.; Nagamori, T.; et al. Th17 cell induction by adhesion of microbes to intestinal epithelial cells. Cell 2015, 163, 367-380. [CrossRef] [PubMed]

86. Ivanov, I.I.; Atarashi, K.; Manel, N.; Brodie, E.L.; Shima, T.; Karaoz, U.; Wei, D.; Goldfarb, K.C.; Santee, C.A.; Lynch, S.V.; et al. Induction of intestinal th17 cells by segmented filamentous bacteria. Cell 2009, 139, 485-498. [CrossRef] [PubMed]

87. Ivanov, I.I.; Frutos Rde, L.; Manel, N.; Yoshinaga, K.; Rifkin, D.B.; Sartor, R.B.; Finlay, B.B.; Littman, D.R. Specific microbiota direct the differentiation of IL-17-producing t-helper cells in the mucosa of the small intestine. Cell Host Microbe 2008, 4, 337-349. [CrossRef] [PubMed]

88. Ivanov, I.I.; McKenzie, B.S.; Zhou, L.; Tadokoro, C.E.; Lepelley, A.; Lafaille, J.J.; Cua, D.J.; Littman, D.R. The orphan nuclear receptor rorgammat directs the differentiation program of proinflammatory il-17+ T helper cells. Cell 2006, 126, 1121-1133. [CrossRef] [PubMed]

89. Mangan, P.R.; Harrington, L.E.; O'Quinn, D.B.; Helms, W.S.; Bullard, D.C.; Elson, C.O.; Hatton, R.D.; Wahl, S.M.; Schoeb, T.R.; Weaver, C.T. Transforming growth factor-beta induces development of the $\mathrm{t}(\mathrm{h}) 17$ lineage. Nature 2006, 441, 231-234. [CrossRef] [PubMed]

90. Low, E.N.; Zagieboylo, L.; Martino, B.; Wilson, E. Iga asc accumulation to the lactating mammary gland is dependent on vcam-1 and alpha4 integrins. Mol. Immunol. 2010, 47, 1608-1612. [CrossRef] [PubMed]

91. Morteau, O.; Gerard, C.; Lu, B.; Ghiran, S.; Rits, M.; Fujiwara, Y.; Law, Y.; Distelhorst, K.; Nielsen, E.M.; Hill, E.D.; et al. An indispensable role for the chemokine receptor ccr10 in iga antibody-secreting cell accumulation. J. Immunol. 2008, 181, 6309-6315. [CrossRef] [PubMed]

92. Rainard, P.; Cunha, P.; Bougarn, S.; Fromageau, A.; Rossignol, C.; Gilbert, F.B.; Berthon, P. T helper 17-associated cytokines are produced during antigen-specific inflammation in the mammary gland. PLoS ONE 2013, 8, e63471. [CrossRef] [PubMed]

93. Wadsworth, S.J.; Atsuta, R.; McIntyre, J.O.; Hackett, T.L.; Singhera, G.K.; Dorscheid, D.R. Il-13 and th2 cytokine exposure triggers matrix metalloproteinase 7-mediated fas ligand cleavage from bronchial epithelial cells. J. Allergy Clin. Immunol. 2010, 126, 366-374. [CrossRef] [PubMed]

94. Chizzolini, C.; Rezzonico, R.; De Luca, C.; Burger, D.; Dayer, J.M. Th2 cell membrane factors in association with il-4 enhance matrix metalloproteinase-1 (mmp-1) while decreasing mmp-9 production by granulocyte-macrophage colony-stimulating factor-differentiated human monocytes. J. Immunol. 2000, 164, 5952-5960. [CrossRef] [PubMed]

95. Darby, I.A.; Hewitson, T.D. Fibroblast differentiation in wound healing and fibrosis. Int. Rev. Cytol. 2007, 257, 143-179. [PubMed]

96. Desmouliere, A.; Geinoz, A.; Gabbiani, F.; Gabbiani, G. Transforming growth factor-b1 induces a-smooth muscle actin expression in granulation tissue myofibroblasts and in quiescent and growing cultured fibroblasts. J. Cell Biol. 1993, 122, 103-111. [CrossRef]

97. Evans, R.; Tian, Y.; Steadman, R.; Phillips, A. Tgf-b1-mediated fibroblast-myofibroblast terminal differentiation-The role of smad proteins. Exp. Cell Res. 2003, 282, 90-100. [CrossRef]

98. Annes, J.; Munger, J.; Rifkin, D. Making sense of latent TGF- $\beta$ activation. J. Cell Sci. 2003, 116, $217-224$. [CrossRef] [PubMed]

99. Lyons, R.M.; Keski-Oja, J.; Moses, H.L. Proteolytic activation of latent transforming growth factor-beta from fibroblast-conditioned medium. J. Cell Biol. 1988, 106, 1659-1665. [CrossRef] [PubMed]

100. Yu, Q.; Stamenkovic, I. Cell surface-localized matrix metalloproteinase-9 proteolytically activates TGF-beta and promotes tumor invasion and angiogenesis. Genes Dev. 2000, 14, 163-176. [PubMed]

101. Van De Water, L.; Varney, S.; Tomasek, J.J. Mechanoregulation of the myofibroblast in wound contraction, scarring, and fibrosis: Opportunities for new therapeutic intervention. Adv. Wound Care 2013, 2, 122-141. [CrossRef] [PubMed]

102. Hinz, B. Formation and function of the myofibroblast during tissue repair. J. Investig. Dermatol. 2007, 127, 526-537. [CrossRef] [PubMed]

103. Hinz, B.; Celetta, G.; Tomasek, J.J.; Gabbiani, G.; Chaponnier, C. Alpha-smooth muscle actin expression upregulates fibroblast contractile activity. Mol. Biol. Cell 2001, 12, 2730-2741. [CrossRef] [PubMed]

104. Muro, A.F.; Chauhan, A.K.; Gajovic, S.; Iaconcig, A.; Porro, F.; Stanta, G.; Baralle, F.E. Regulated splicing of the fibronectin eda exon is essential for proper skin wound healing and normal lifespan. J. Cell Biol. 2003, 162, 149-160. [CrossRef] [PubMed] 
105. McDaniel, S.M.; Rumer, K.K.; Biroc, S.L.; Metz, R.P.; Singh, M.; Porter, W.; Schedin, P. Remodeling of the mammary microenvironment after lactation promotes breast tumor cell metastasis. Am. J. Pathol. 2006, 168, 608-620. [CrossRef] [PubMed]

106. Goddard, E.T.; Hill, R.C.; Barrett, A.; Betts, C.; Guo, Q.; Maller, O.; Borges, V.F.; Hansen, K.C.; Schedin, P. Quantitative extracellular matrix proteomics to study mammary and liver tissue microenvironments. Int. J. Biochem. Cell Biol. 2016, 81, 223-232. [CrossRef] [PubMed]

107. Schedin, P.; Strange, R.; Mitrenga, T.; Wolfe, P.; Kaeck, M. Fibronectin fragments induce mmp activity in mouse mammary epithelial cells: Evidence for a role in mammary tissue remodeling. J. Cell Sci. 2000, 113, 795-806. [PubMed]

108. Schafer, M.; Werner, S. Cancer as an overhealing wound: An old hypothesis revisited. Nat. Rev. 2008, 9, 628-638. [CrossRef] [PubMed]

109. Provenzano, P.P.; Inman, D.R.; Eliceiri, K.W.; Knittel, J.G.; Yan, L.; Rueden, C.T.; White, J.G.; Keely, P.J. Collagen density promotes mammary tumor initiation and progression. BMC Med. 2008, 6, 11. [CrossRef] [PubMed]

110. Keely, P.J. Mechanisms by which the extracellular matrix and integrin signaling act to regulate the switch between tumor suppression and tumor promotion. J. Mammary Gland Biol. Neoplasia 2011, 16, 205-219. [CrossRef] [PubMed]

111. Cheng, N.; Bhowmick, N.A.; Chytil, A.; Gorksa, A.E.; Brown, K.A.; Muraoka, R.; Arteaga, C.L.; Neilson, E.G.; Hayward, S.W.; Moses, H.L. Loss of TGF-beta type ii receptor in fibroblasts promotes mammary carcinoma growth and invasion through upregulation of TGF-alpha-, msp- and hgf-mediated signaling networks. Oncogene 2005, 24, 5053-5068. [CrossRef] [PubMed]

112. Fang, W.B.; Jokar, I.; Chytil, A.; Moses, H.L.; Abel, T.; Cheng, N. Loss of one tgfbr2 allele in fibroblasts promotes metastasis in mmtv: Polyoma middle transgenic and transplant mouse models of mammary tumor progression. Clin. Exp. Metastasis 2011, 28, 351-366. [CrossRef] [PubMed]

113. Shen, B.; Zheng, M.Q.; Lu, J.W.; Jiang, Q.; Wang, T.H.; Huang, X.E. Cxcl12-cxcr4 promotes proliferation and invasion of pancreatic cancer cells. Asian Pac. J. Cancer Prev. 2013, 14, 5403-5408. [CrossRef] [PubMed]

114. Liu, P.; Long, P.; Huang, Y.; Sun, F.; Wang, Z. Cxcl12/cxcr4 axis induces proliferation and invasion in human endometrial cancer. Am. J. Transl. Res. 2016, 8, 1719-1729. [PubMed]

115. Bleul, C.C.; Fuhlbrigge, R.C.; Casasnovas, J.M.; Aiuti, A.; Springer, T.A. A highly efficacious lymphocyte chemoattractant, stromal cell-derived factor 1 (sdf-1). J. Exp. Med. 1996, 184, 1101-1109. [CrossRef] [PubMed]

116. Chatterjee, M.; von Ungern-Sternberg, S.N.; Seizer, P.; Schlegel, F.; Buttcher, M.; Sindhu, N.A.; Muller, S.; Mack, A.; Gawaz, M. Platelet-derived cxcl12 regulates monocyte function, survival, differentiation into macrophages and foam cells through differential involvement of cxcr4-cxcr7. Cell Death Dis. 2015, 6, e1989. [CrossRef] [PubMed]

117. Achyut, B.R.; Bader, D.A.; Robles, A.I.; Wangsa, D.; Harris, C.C.; Ried, T.; Yang, L. Inflammation-mediated genetic and epigenetic alterations drive cancer development in the neighboring epithelium upon stromal abrogation of TGF-beta signaling. PLoS Genet. 2013, 9, e1003251. [CrossRef] [PubMed]

118. Franco, O.E.; Jiang, M.; Strand, D.W.; Peacock, J.; Fernandez, S.; Jackson, R.S., 2nd; Revelo, M.P.; Bhowmick, N.A.; Hayward, S.W. Altered TGF-beta signaling in a subpopulation of human stromal cells promotes prostatic carcinogenesis. Cancer Res. 2011, 71, 1272-1281. [CrossRef] [PubMed]

119. Digiacomo, G.; Ziche, M.; Dello Sbarba, P.; Donnini, S.; Rovida, E. Prostaglandin e2 transactivates the colony-stimulating factor-1 receptor and synergizes with colony-stimulating factor- 1 in the induction of macrophage migration via the mitogen-activated protein kinase erk1/2. FASEB J. 2015, 29, 2545-2554. [CrossRef] [PubMed]

120. Greenhough, A.; Smartt, H.J.; Moore, A.E.; Roberts, H.R.; Williams, A.C.; Paraskeva, C.; Kaidi, A. The cox-2/pge2 pathway: Key roles in the hallmarks of cancer and adaptation to the tumour microenvironment. Carcinogenesis 2009, 30, 377-386. [CrossRef] [PubMed]

121. Zelenay, S.; van der Veen, A.G.; Bottcher, J.P.; Snelgrove, K.J.; Rogers, N.; Acton, S.E.; Chakravarty, P.; Girotti, M.R.; Marais, R.; Quezada, S.A.; et al. Cyclooxygenase-dependent tumor growth through evasion of immunity. Cell 2015, 162, 1257-1270. [CrossRef] [PubMed]

122. Zaslona, Z.; Serezani, C.H.; Okunishi, K.; Aronoff, D.M.; Peters-Golden, M. Prostaglandin e2 restrains macrophage maturation via e prostanoid receptor 2/protein kinase a signaling. Blood 2012, 119, 2358-2367. [CrossRef] [PubMed] 
123. Montrose, D.C.; Zhou, X.K.; McNally, E.M.; Sue, E.; Yantiss, R.K.; Gross, S.S.; Leve, N.D.; Karoly, E.D.; Suen, C.S.; Ling, L.; et al. Celecoxib alters the intestinal microbiota and metabolome in association with reducing polyp burden. Cancer Prev. Res. 2016, 9, 721-731. [CrossRef] [PubMed]

124. Lee, S.Y.; Choi, H.K.; Lee, K.J.; Jung, J.Y.; Hur, G.Y.; Jung, K.H.; Kim, J.H.; Shin, C.; Shim, J.J.; In, K.H.; et al. The immune tolerance of cancer is mediated by ido that is inhibited by cox-2 inhibitors through regulatory T cells. J. Immunother. 2009, 32, 22-28. [CrossRef] [PubMed]

125. Na, Y.R.; Yoon, Y.N.; Son, D.I.; Seok, S.H. Cyclooxygenase-2 inhibition blocks $\mathrm{m} 2$ macrophage differentiation and suppresses metastasis in murine breast cancer model. PLoS ONE 2013, 8, e63451. [CrossRef] [PubMed]

126. Esbona, K.; Inman, D.; Saha, S.; Jeffery, J.; Schedin, P.; Wilke, L.; Keely, P. Cox-2 modulates mammary tumor progression in response to collagen density. Breast Cancer Res. 2016, 18, 35. [CrossRef] [PubMed]

127. Callihan, E.B.; Gao, D.; Jindal, S.; Lyons, T.R.; Manthey, E.; Edgerton, S.; Urquhart, A.; Schedin, P.; Borges, V.F. Postpartum diagnosis demonstrates a high risk for metastasis and merits an expanded definition of pregnancy-associated breast cancer. Breast Cancer Res. Treat. 2013, 138, 549-559. [CrossRef] [PubMed]

128. Collins, L.C.; Gelber, S.; Marotti, J.D.; White, S.; Ruddy, K.; Brachtel, E.F.; Schapira, L.; Come, S.E.; Borges, V.F.; Schedin, P.; et al. Molecular phenotype of breast cancer according to time since last pregnancy in a large cohort of young women. Oncologist 2015, 20, 713-718. [CrossRef] [PubMed]

(c) 2017 by the authors; licensee MDPI, Basel, Switzerland. This article is an open access article distributed under the terms and conditions of the Creative Commons Attribution (CC-BY) license (http://creativecommons.org/licenses/by/4.0/). 